\title{
The intracerebral infection of mice with Bordetella pertussis
}

\author{
By JEAN M. DOLBY AND A. F. B. STANDFAST \\ The Lister Institute of Preventive Medicine, Elstree, Hertfordshire
}

(Received 4 January 1961)

\section{INTRODUCTION}

The intracerebral infection of mice with Bordetella pertussis was first suggested by Norton as a result of the successful use of this route with Salmonella typhi (Norton \& Dingle, 1935). The assay of pertussis vaccines using the intracerebral route for the challenge was developed in the U.S.A., particularly by Kendrick and Pittman (Kendrick, Eldering, Dixon \& Misner, 1947; U.S., N.I.H., 1948, Minimum Requirements; Pittman, 1956).

In 1937 Burnet \& Timmins (1937) described the intranasal technique for the infection of mice with $B$. pertussis. For a time it seemed that assays of pertussis vaccines using either route for the challenge were equally valid. Further experience showed that whereas many vaccines successfully pass both tests, certain vaccines pass one test and not the other, and that a series of vaccines might be arranged in quite different orders of potency by the two tests. The antigen responsible for protecting children appears to be that protecting mice against challenge by the intracerebral route and not that protecting mice against a challenge by the intranasal route (Standfast, 1958). A difference in the antibodies protecting against the two types of challenge was demonstrated in passive protection tests (Dolby \& Standfast, 1958).

In this paper the results obtained by following the course of infection in the brains of untreated, actively immunized and passively protected mice are presented. Protection against an intracerebral infection involves a mechanism quite distinct from the mechanism of protection against an intranasal infection already described (Dolby, Thow \& Standfast, 1961).

\section{Infecting suspensions}

\section{METHODS}

Most of the experiments were made with strain no. 18-323 (NCTC 9797) isolated by Dr P. Kendrick. Its LD 50 by the intracerebral route is $c .10^{2.0}$ in mice of strain C1. Only very occasionally are other strains of $B$. pertussis found of similar intracerebral virulence; for most strains the LD 50 lies between $10^{5.9}$ and $10^{9.6}$ in Cl mice. Other strains of $B$. pertussis used are recorded below. The strains were grown on Bordet-Gengou medium for $20 \mathrm{hr}$. at $36^{\circ}$, harvested into $1 \%$ Difco Casamino acids (commercial grade) and standardized against the National Institutes of Health opacity standard, which is equivalent to 10,000 million B. pertussis per ml. Further dilutions were made as required in $1 \%$ aqueous Casamino acids. 
Viable counts were made of all suspensions. The viability of the Casamino acid suspensions remained stable for $3 \mathrm{hr}$. The routine inoculum in assays and protection tests was 50,000 organisms by opacity (total count), of which $c .10 \%$ were viable. This dose contains $c .200 \mathrm{LD} 50$.

\section{Viable counts}

At intervals, groups of 5 or 10 mice were killed with coal gas and their brains were removed aseptically. Each brain, treated separately, was placed in $10 \mathrm{ml}$. $1 \%$ aqueous Difco Casamino acids (commercial grade) in a 2 oz. Universal bottle containing about $2 \mathrm{ml}$. glass beads $(5 \mathrm{~mm}$. diam.) and shaken for $3 \mathrm{~min}$. on a vertical shaker $2 \frac{3}{4}$ in. throw, 325 r.p.m. Mice dying from the infection on the day of the count were included. Serial tenfold dilutions were made in $1 \%$ Casamino acids and plated out on Bordet-Gengou plates and counts made by the method of Miles \& Misra (1938). For counts in brains receiving the small infecting doses during the first two days of infection, $0.5 \mathrm{ml}$. of the homogenate or of a $1 / 10$ dilution were spread over the surface of a Bordet-Gengou plate. The numbers of organisms are expressed as the geometric mean of counts from all the mice within the group.

\section{Passive protection tests}

Suitable dilutions of rabbit antisera were given intraperitoneally $4 \mathrm{hr}$. before the challenge (c. 200 LD 50) B. pertussis suspension was given by the intracerebral route (see Dolby \& Standfast, 1958).

\section{Rabbit antisera}

Rabbit antisera to bacteria and toxin were prepared as before (Dolby \& Standfast, 1958). In addition, an antiserum was prepared against fraction $K 1$ (Dolby, 1958); this serum was highly protective against an intracerebral challenge but did not protect against an intranasal challenge. Pure antitoxin was obtained by absorbing a serum prepared against a Hughes press extract of bacilli (Hughes, 1951) with heavy suspensions of formalin-treated whole bacterial cells (after neutralization of excess formalin) until the serum failed to protect mice against infection with living organisms. The absorbed serum neutralized toxin and protected mice against lethal doses of toxin given by the intraperitoneal route.

\section{Active immunization tests}

Suitable doses of the vaccine under test, usually 2000,800 and 40 million organisms, were injected intraperitoneally in $\mathbf{0 . 2} \mathrm{ml}$. volumes into groups of mice 10 days before the challenge (c. $200 \mathrm{LD} 50$ ) was given by the intracerebral route (see Standfast, 1958).

\section{Definitions and abbreviations}

Throughout this paper 'intracerebral' antigen means the antigen which protects mice against a challenge by the intracerebral route; 'intracerebral' antibody means antibody which protects mice against a challenge by the intracerebral route. 
A similar system applies to 'intranasal' antigen and 'intranasal' antibody. The route of administration of antigen, challenge or serum is always referred to as the intracerebral route, etc. Abbreviations $I C, I N$ and $I P$ are used for intracerebral, intranasal and intraperitoneal when it is necessary to abbreviate.

\section{RESULTS}

\section{The fate of the inoculum in the mouse's brain}

Strain 18-323 injected by the intracerebral route into mice multiplied without difficulty from small inocula. There was a considerable immediate loss of the inoculum amounting to at least $90 \%$ of the bacteria injected.

Viable counts carried out immediately after the injection of the inoculum, and $2 \mathrm{hr}$. later showed that the average drop was from $10^{3 \cdot 6}$ to $10^{2 \cdot 4}$ or from $10^{2 \cdot 6}$ to $10^{1.6} ;$ by $24 \mathrm{hr}$. growth had brought the count up to a figure similar to the inoculum. The injected dose is referred to as the inoculum. The figure for the $2 \mathrm{hr}$. count, which was about $10 \%$ of the inoculum, is always referred to as the infecting dose. Cairns (1950) first reported this immediate loss of the greater part of an intracerebral inoculum which he showed spills over into the bloodstream. Dr L. E. Holt (private communication) first drew our attention to the fate of indian ink injected by the intracerebral route in mice; the ink can easily be shown in the ventricles and right down the spinal cord. Mims (1960) deals more fully with the fate of indian ink injected by this route into mice, and describes its distribution in the subarachnoid space, the ventricles and the central canal.

\section{The growth of Bordetella pertussis in the brain}

Fig. 1 shows five typical growth curves for $B$. pertussis, strain 18-323, in the brains of mice given inocula varying from $10^{1 \cdot 4}$ to $10^{8 \cdot 6}$. In all the curves the $2 \mathrm{hr}$. count shows a drop of about $90 \%$; unfortunately there was no $2 \mathrm{hr}$. count in the $10^{8 \cdot 6}$ experiment. In $24 \mathrm{hr}$. the counts have reached or even passed the original inoculum.

The increase in viable counts for a series of increasing doses of $B$. pertussis shown in Fig. 2 are of the pooled results of several experiments so that each point is the geometric mean count of at least 30 mice. The counts rise steadily to a value between $10^{7 \cdot 5}$ and $10^{8}$, when the mice start to die.

The curves indicate a reasonably rapid growth for the first day or so and then a progressive slowing, owing either to increasing immunity or perhaps to exhaustion of nutrients for the bacteria.

In most experiments the rate of increase in viable count was about the same and the first deaths occurred on the 6th day (Fig. 3d), but in three experiments the first deaths were on the 8th, 11th and 14th day (Fig. 3a-c). The longer time to death was due to a slower rate of growth from the $2 \mathrm{hr}$. count, and not to a smaller inoculum.

These approximately parallel curves (Fig. 2) suggest that with a virulent strain the rate of increase is the same for all inocula; that the time of death depends on 


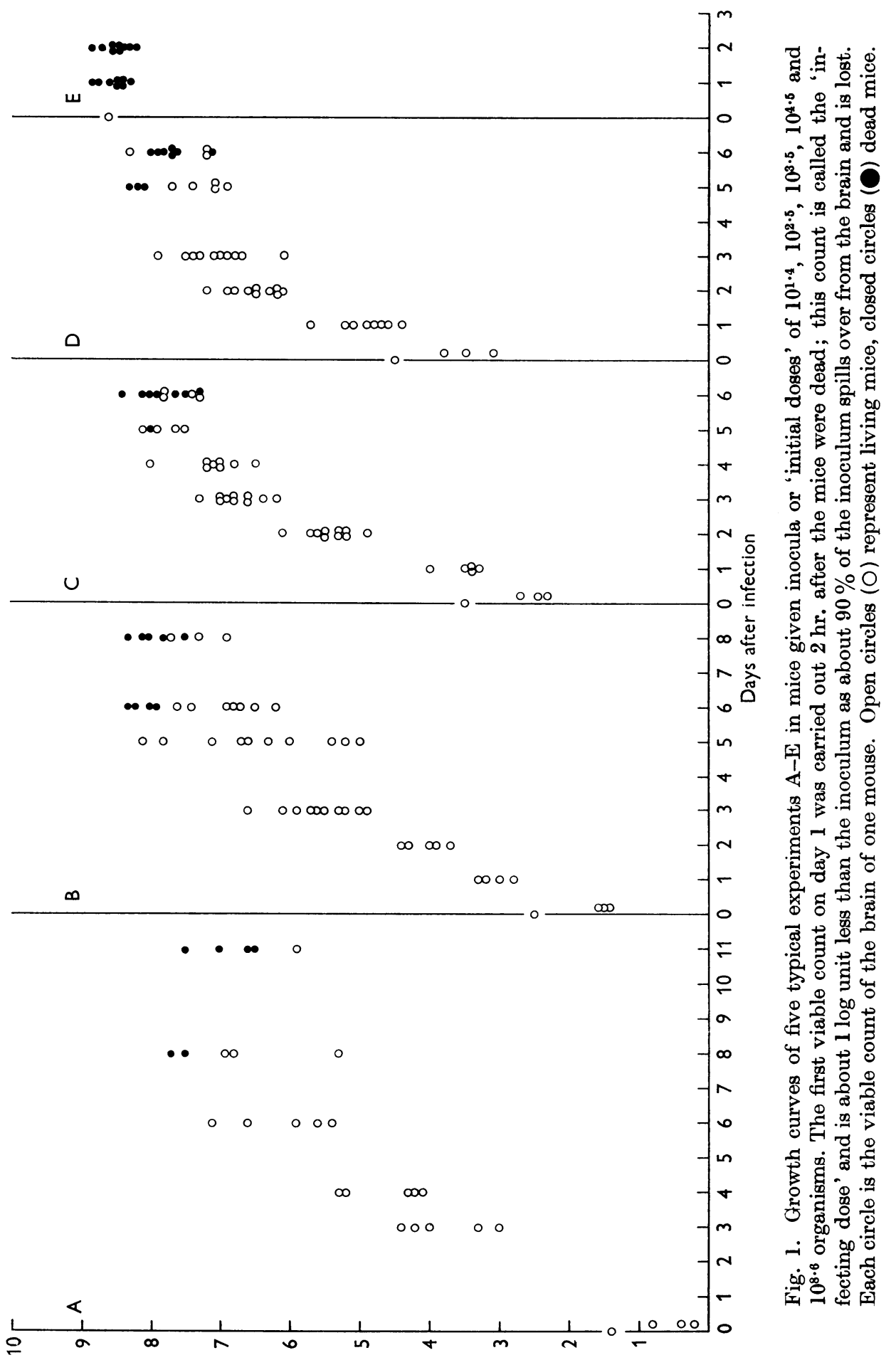


the size of the inoculum; and that the longer the time to death, the lower the terminal count, which was $10^{8 \cdot 1}$ at 5 days and $10^{7 \cdot 4}$ at 11 days.

The growth of a virulent strain in the brain is rather different from the growth in the lung (Dolby, Thow \& Standfast, 1961). Small inocula of virulent intranasal strains increase and then decline, producing a sublethal infection. Infection by a virulent intracerebral strain, if growth occurs, is always lethal. Thus, the smallest inoculum in the series of experiments shown in Fig. 2, c. 30 viable organisms, eventually reached the lethal level at 11 days. Fig. 4 records the counts in the

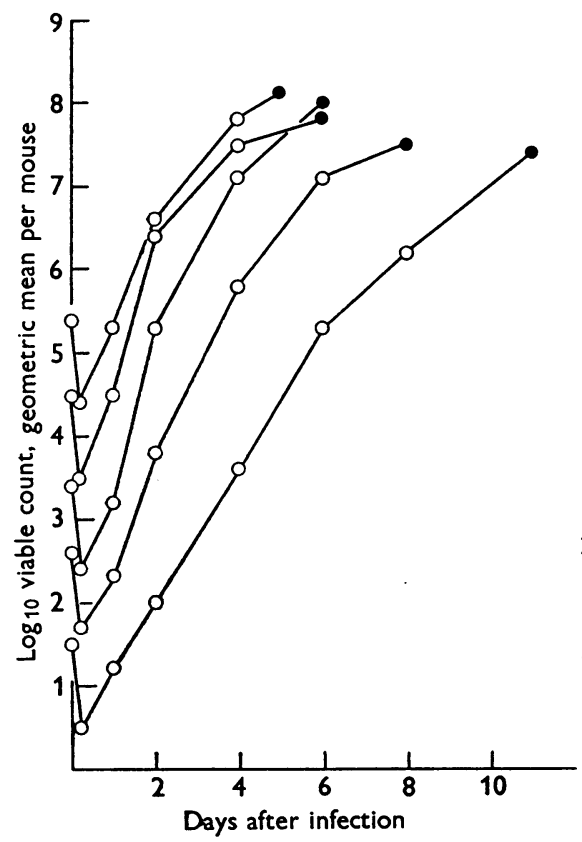

Fig. 2

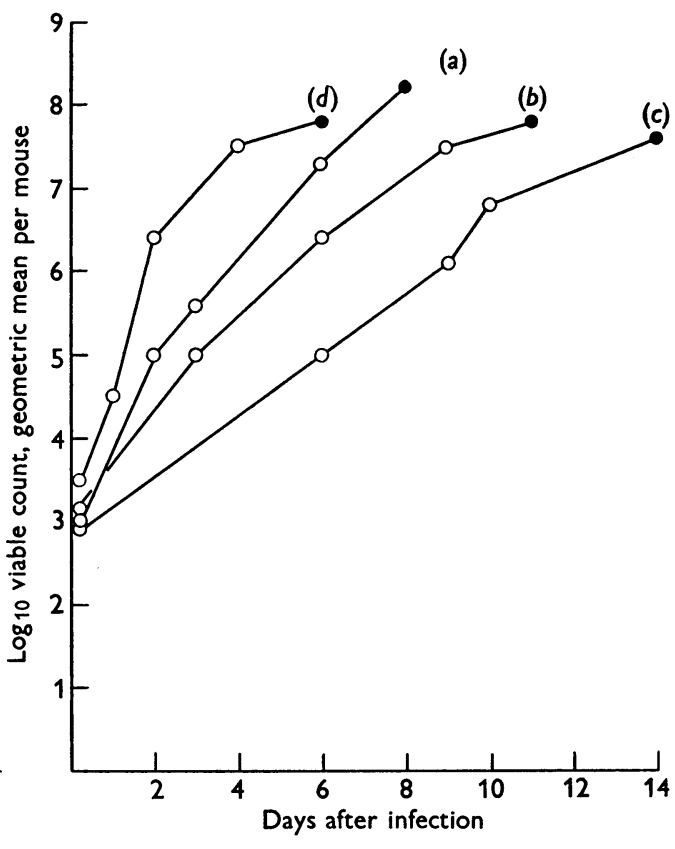

Fig. 3

Fig. 2. The logarithms of the mean viable counts up to the day of the first death for groups of mice infected with increasing inocula of Bordetella pertussis, strain 18-323, plotted against time (days after infection). Each point is the mean of at least $30 \mathrm{mice}$. Open circles (O) represent living mice, closed circles (O) dead mice.

Fig. 3. The logarithms of the mean viable counts for three groups of mice given infecting doses of c. $10^{3}$ Bordetella pertussis. In these three experiments, the first deaths were recorded on the 8 th, curve $a$, 11th, curve $b$, and 14th, curve c, days. Curve $d$ (from Fig. 2), with the first death on the 6th day, is the usually found curve for doses c. $10^{4}$. Open circles (O) represent living mice, closed circles (O) dead mice.

brains of single mice given very small inocula between $10^{0.5}$ and $10^{1 \cdot 5}$. There is no decline in the viable count from the 6th day as in lungs during sublethal infection, or in the brain during the sublethal infection investigated by Blyth (1955) or Andersen (1957) with other strains of $B$. pertussis and other strains of mice.

Mice were injected with a suspension calculated to contain three organisms or less and 5 mice were killed daily from the 2 nd to the 14th day. Three positive counts were obtained; on the $3 \mathrm{rd}$ day $10^{3 \cdot 40}$; on the 4 th day $10^{4 \cdot 93}$ and on the 8 th 
day $10^{7.39}$, forming a growth curve similar to those of larger doses; the remainder of the brains were sterile. Our figures are consistent with the hypothesis that the smallest inoculum that begins to grow in the brain will multiply eventually to a lethal level.

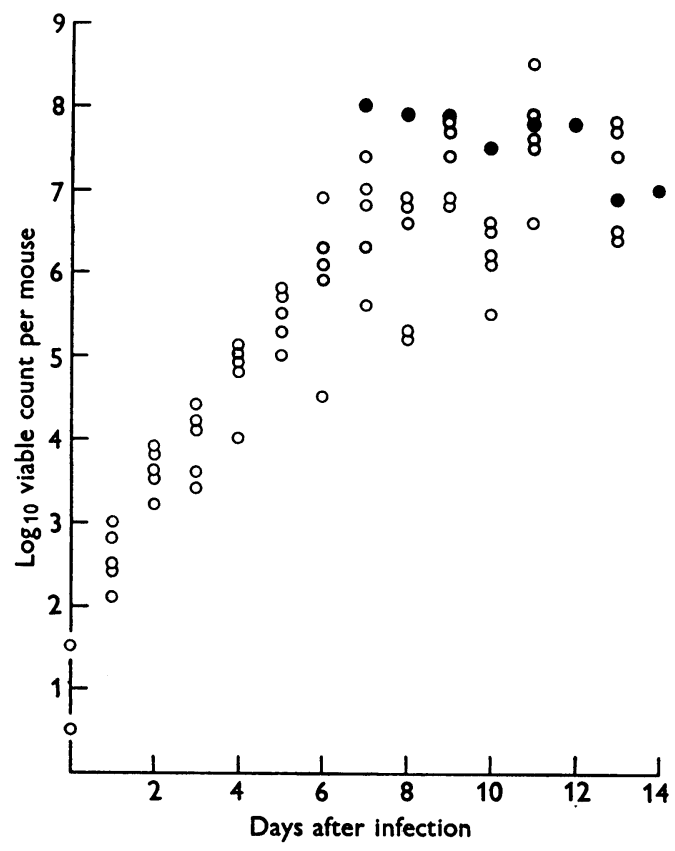

Fig. 4. Viable counts of individual living mice in all experiments in which the inoculum ( $1 \mathrm{LD} 50$ or less) was between $10^{\circ .5}$ and $10^{1.5}$ viable organisms. The closed circles (O) are the mean terminal counts for all mice for each day from 7 to 14 .

Table 1. Accumulated numbers of sterile brains in groups of mice given different inocula of Bordetella pertussis, strain 18-323, by the intracerebral route

(There is no obvious increase in the percentage of sterile brains with time.)

\begin{tabular}{|c|c|c|c|c|c|c|c|}
\hline \multicolumn{2}{|c|}{ Inoculum } & \multicolumn{6}{|c|}{ Day } \\
\hline Total count & Viable count & 3 & 5 & 7 & 9 & 11 & 13 \\
\hline 50 & $\begin{array}{r}5 \\
\text { or less }\end{array}$ & $\begin{array}{l}14 / 15 \\
93 \%\end{array}$ & $\begin{array}{c}23 / 25 \\
92 \%\end{array}$ & $\begin{array}{c}38 / 39 \\
95 \%\end{array}$ & $\begin{array}{l}44 / 47 \\
94 \%\end{array}$ & $\begin{array}{l}58 / 61 \\
95 \%\end{array}$ & $\begin{array}{l}73 / 75 \\
97 \%\end{array}$ \\
\hline 500 & 35 & $\begin{array}{l}12 / 14 \\
86 \%\end{array}$ & $\begin{array}{l}19 / 25 \\
76 \%\end{array}$ & $\begin{array}{l}27 / 40 \\
68 \%\end{array}$ & $\begin{array}{l}32 / 50 \\
64 \%\end{array}$ & $\begin{array}{l}40 / 62 \\
65 \%\end{array}$ & $\begin{array}{l}52 / 75 \\
69 \%\end{array}$ \\
\hline 5,000 & 300 & $\begin{array}{r}3 / 28 \\
11 \%\end{array}$ & $\begin{array}{r}4 / 38 \\
11 \%\end{array}$ & $\begin{array}{l}5 / 61 \\
8 \%\end{array}$ & $\begin{array}{l}7 / 76 \\
9 \%\end{array}$ & $\begin{array}{r}12 / 90 \\
13 \%\end{array}$ & $\begin{array}{r}12 / 93 \\
13 \%\end{array}$ \\
\hline 50,000 & 4,000 & $\begin{array}{r}8 / 53 \\
15 \%\end{array}$ & $\begin{array}{c}10 / 111 \\
9 \%\end{array}$ & $\begin{array}{c}12 / 156 \\
8 \%\end{array}$ & - & - & - \\
\hline 50,000 & 40,000 & $\begin{array}{l}5 / 131 \\
4 \%\end{array}$ & $\begin{array}{l}9 / 200 \\
4 \%\end{array}$ & $\begin{array}{c}12 / 249 \\
5 \%\end{array}$ & - & - & - \\
\hline $5,000,000$ & 330,000 & $\begin{array}{l}0 / 10 \\
0 \%\end{array}$ & $\begin{array}{l}0 / 10 \\
0 \%\end{array}$ & $\begin{array}{l}0 / 10 \\
0 \%\end{array}$ & - & - & - \\
\hline
\end{tabular}




\section{Sterile brains}

Corroborative evidence that there is no decrease in viable count is shown in Table 1. Though the percentage of sterile brains varies with the infecting dose, the percentage of sterile brains in the cumulative series for a given dose remains remarkably constant from the 5th day to the 14th day. There is no rise in the percentage of sterile brains, as would happen if the mice were freeing themselves of the infecting organism.

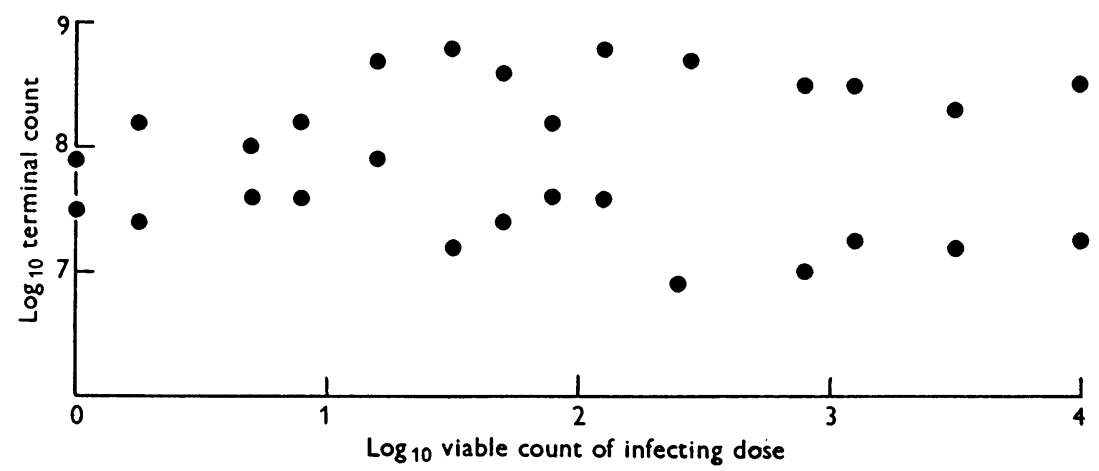

Fig. 5. The logarithm of the observed terminal viable count of mouse brains plotted against the logarithm of the infecting dose, showing that the terminal count is approximately constant for all doses. The figures are shown only of the highest and lowest individual counts for each infecting dose.

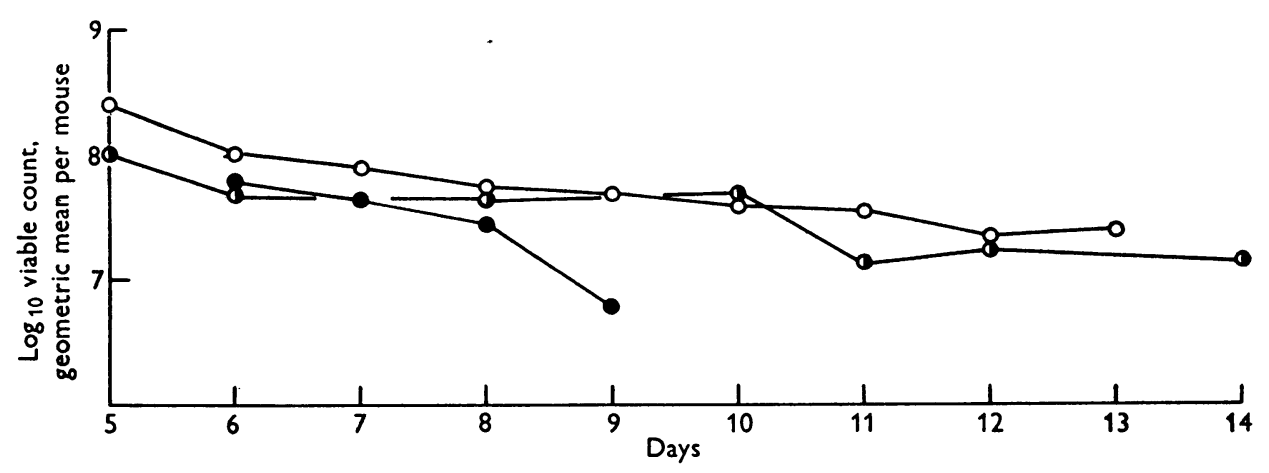

Fig. 6. Geometric mean terminal viable count amongst untreated, vaccinated and serum treated mice plotted against time, showing the tendency for the terminal viable count to diminish with time. $O=$ Untreated mice; $0=$ vaccinated mice and $O=$ serum treated mice.

\section{Terminal count in infected mice}

The terminal viable count was approximately constant at c. $10^{8}$ regardless of the infecting dose (Fig. 5). The figures given for each infecting dose show the highest individual count and the lower individual count of any mouse given that dose. Although the terminal count did not vary with the infecting dose, it tended to fall as the time to death increased (see also Figs. 2-4).

In infected mice which failed to respond to or benefit from serum or vaccine 
treatment, the terminal count was of the same order as normal mice given the same infecting dose. In mice which responded to treatment, of course, the brain counts were well below the lethal level.

Fig. 6 shows the mean terminal counts for groups of control mice, vaccinated mice and serum treated mice. The terminal count falls with time in all three groups suggesting that the 'lethal toxins' from an infecting dose that increased from $10^{2 \cdot 5}$ to $10^{6.8}$ in 9 days have the same lethal effect on the 9 th day as those from the dose that grew from $10^{2 \cdot 5}$ to $10^{7.8}$ in 6 days have on the 6 th day.

\section{Toxic dose}

Mice are more susceptible to $B$. pertussis toxin administered by the intracerebral route than by any other route. The TD 50 (toxic dose killing $50 \%$ of mice) of toxin preparation no. 5353 was $0 \cdot 125 \mu$ by the intracerebral route, $1.3 \mu$ by the intraperitoneal route. The TD50 IC of this toxin (no. 5353) was contained in $10^{7.5}$ bacterial cells; the TD50 IC for eight other toxin preparations were contained in $8.3 \times 10^{7}$ to $5.5 \times 10^{9}$ bacterial cells, numbers which are similar to the terminal count of $c .10^{8}$.

Sections of brains of infected mice at 6 days, just before death, look very similar to those of mice which have received a lethal dose of toxin intracerebrally. The matrix of the cerebral hemispheres has disintegrated, the nuclei of the astrocytes and oligodendrocytes have disappeared and red blood cells, granulocytes and small round cells with strongly staining nuclei are scattered throughout the section. At about the 4th day after infection, the Purkinje cells of the cerebellum begin to lose their staining properties.

If death is due to toxin, antitoxin given intracerebrally should be protective. However, samples of our antitoxin injected into the brain 2, 3, 4 and 5 days after infection were without effect, either in increased survival time or in raised terminal counts.

\section{Intracerebral infection in passively protected mice}

The course of an intracerebral infection was followed in groups of mice given potent 'intracerebral' pertussis antisera by the intraperitoneal route 3 days (Fig. 7) or $4 \mathrm{hr}$. (Fig. 8) before, and 1 day or 3 days (Fig. 9) after the challenge given by the intracerebral route.

The results were similar in all cases. The count in the treated mice was of the same order as the controls until the 3rd or 4th day after infection when it fell at a rate depending on the strength and time of administration of the serum. The serum was equally effective given before or up to 3 days after the challenge.

'Intracerebral' serum, whenever given, did not reduce the number of bacteria in the brain until the 3rd or 4th day after infection; this was quite unlike the immediate reduction in numbers of organisms observed in the serum treatment of intranasal infection (Dolby et al. 1961).

The independence of the 3- to 4-day lag and the time of administration of the serum relative to the time of infection appears to be due to the inaccessibility of the brain lesion to circulating antibody until the infection has reached a certain stage, at about 3-4 days (Holt, Spasojevic, Dolby \& Standfast, 1961). 

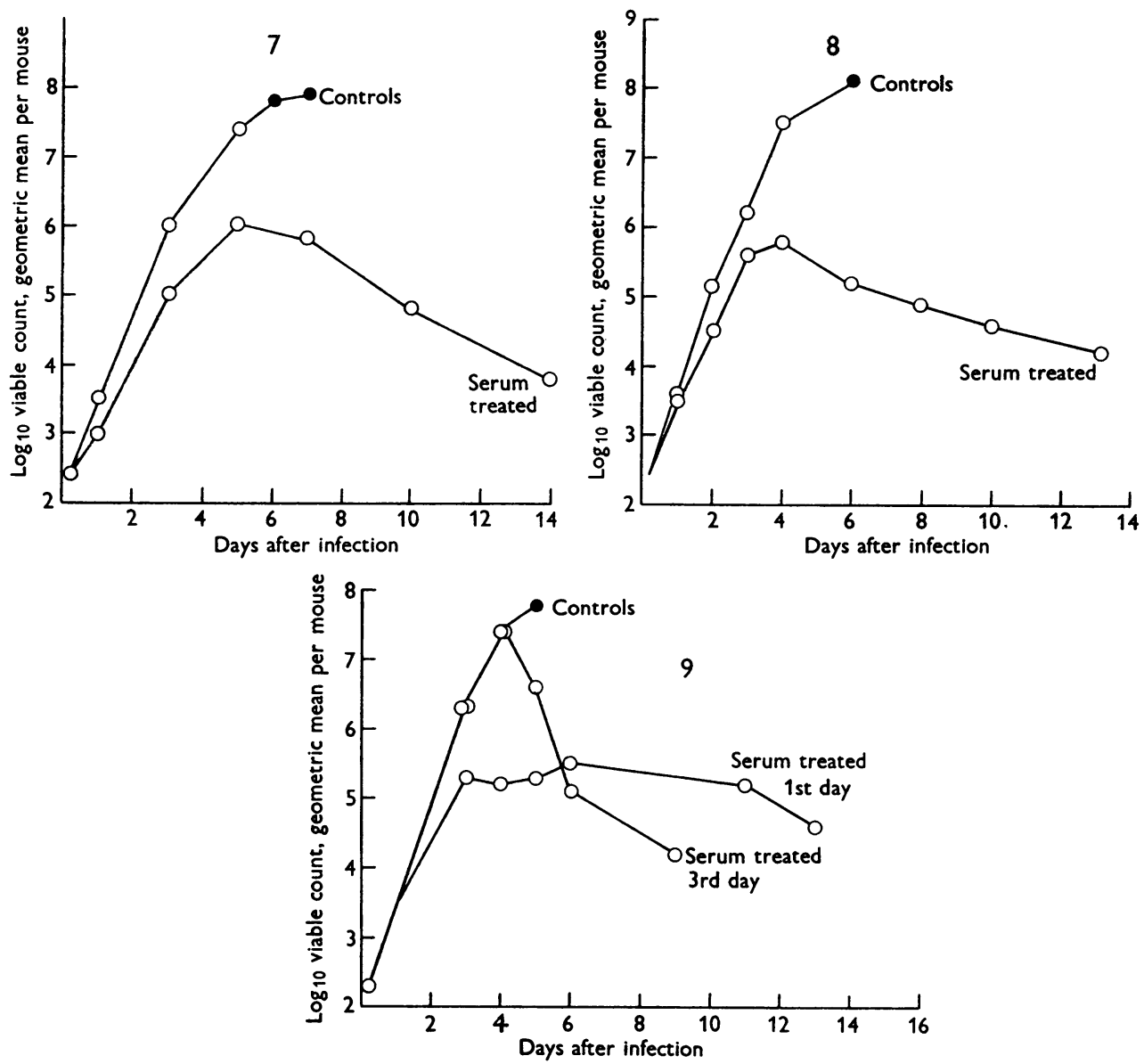

Fig. 7. Growth curves for B. pertussis, strain 18-323, in treated and untreated mice. Treated mice were given anti-pertussis rabbit serum by the intraperitoneal route 3 days before the challenge dose which was given by the intracerebral route. In this experiment 18 out of 20 mice survived at least 14 days in the treated mice and 1 out of 30 survived the 7 th day in the controls.

Fig. 8. Similar growth curves in mice given anti-pertussis rabbit serum $4 \mathrm{hr}$. before the challenge. Seventy-two out of 80 mice survived at least until the 13th day in the treated group and 2 out of 30 survived the 6th day in the controls.

Fig. 9. Growth curves in mice given anti-pertussis rabbit serum 1 day or 3 days after challenge. In the controls no mouse survived the 5th day. In the treated mice 18 out of 20 survived at least 12 days if given serum 1 day after the challenge and 15 out of 20 survived at least 6 days if given the serum 3 days after the challenge. Each point on these graphs is the geometric mean of 5 or 10 mice.

\section{Intracerebral infections in actively immunized mice}

The growth of organisms in the brains of actively immunized mice is very like that in passively protected mice. Mice were given a single dose of vaccine of either 80,400 or 2000 million organisms, and challenged with $50,000 \mathrm{~B}$. pertussis, strain 18-323 (Fig. 10). There were $3 / 30$ survivors with the smallest dose of vaccine 
$\left(80 \times 10^{6}\right), 18 / 29$ with $400 \times 10^{6}$ and $24 / 39$ with the largest dose of vaccine $\left(2000 \times 10^{6}\right)$. There were no survivors among the controls. The terminal count in dead mice in each group was $c$. 10 $0^{8 \cdot 0}$. The successfully vaccinated mice all started to recover about the 4th day. Other experiments with vaccinated mice gave similar results. In all, the 6th day count in surviving mice was considerably lower than the 4th day count, which never rose above $10^{5.8}$ and the growth in mice given large doses of vaccine $\left(2000 \times 10^{6}\right)$ was always slower than in the others.

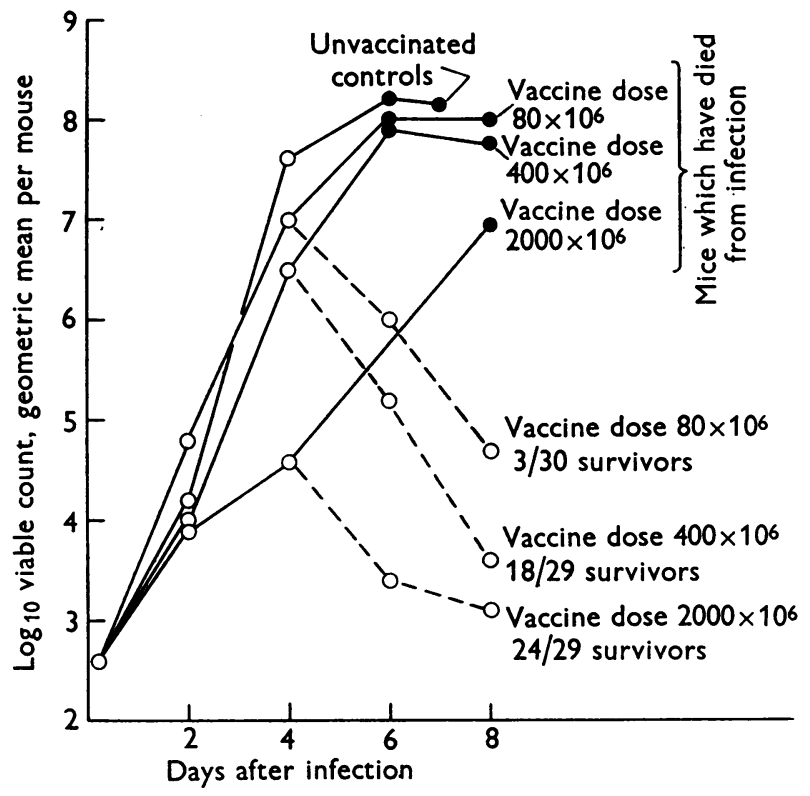

Fig. 10. Growth curves of Bordetella pertussis in mice actively immunized with killed pertussis vaccines at three dose levels, 80, 400, and 2000 million, 14 days before challenge by the intracerebral route. The 30 control unvaccinated mice all died on the 6th or 7th day after challenge; 27 out of 30 mice given 80 million bacilli as vaceine died on the 6th or 8th day; 11 out of 29 mice given 400 million died on the 6th or 8th day and 5 out of 29 mice given 2000 million. There were no more deaths up to the 14th day when the experiment was terminated. No counts were done after the 8th day by which time the count was falling steadily in the surviving mice. Open circles $(O)$ represent living mice, closed circles $(\bullet)$ dead mice.

\section{DISCUSSION AND CONCLUSIONS}

The family of curves obtained for infection with different doses show that the infecting organisms increase at a rate that was constant for all doses in $29 / 32$ instances. The rate of growth in three instances was slower than expected for the infecting dose, though the terminal count for the mouse dying first was that expected. Since the infecting dose was known, the longer time to death 10-14 days instead of 6 days must have been due to the slower growth of the organisms. This slower growth also occurred in passively protected mice (Figs. 7-9) during the first 3 or 4 days of infection, although the striking effect of the serum is not seen until after the 4th day. It is least evident (between the 3rd and 4th days, Fig. 9) in mice given serum 3 days after challenge, when the count is already more than 
106.0. This effect is probably due to some leakage of circulating antibody into the brain before the blood-brain barrier breaks down, assisted perhaps by the local trauma of the intracerebral injection, still present 1 day after but healed by 3 days (Fig. 9). We know by experiment that the blood-brain barrier in mice successfully treated with serum becomes whole again 5-6 days after infection (Holt et al. 1961).

The dramatic fall in the numbers of viable $B$. pertussis at about the 4th day in both actively and passively protected mice is closely correlated with the breakdown of the blood-brain barrier as demonstrated by the marked leakage of Pontamine blue and $\gamma$-globulins at this time (Holt et al. 1961). The line between life and death is a narrow one as a mean count of $10^{7 \cdot 4}$ (Fig. 9) has been found in mice 15/20 of which recovered with serum treatment. In this experiment the count in a group of obviously recovering mice had dropped from $10^{7 \cdot 4}$ to $10^{6 \cdot 6}$ in $24 \mathrm{hr}$. while the untreated controls were all dead with a mean terminal count of $10^{7 \cdot 9}$.

The terminal viable count is more or less constant and independent of the size of the infecting dose though there is some evidence of a small and gradual drop in the terminal count from $10^{8}$ to $10^{7}$ from the 5th to the 14th days after infection.

The mean time to death was never less than 6 days irrespective of the dose and the shortest individual death time 5 days even in experiments in which 200 LD 50 were given. This suggests that death is due to the action of the toxin produced by the infecting bacteria acting over a period of time, with the usual rate of increase this period is about 6 days, rather than the direct action of 100 million viable organisms. This would also explain the fact that the toxic dose of whole bacteria is considerably greater than the terminal count unless the bacteria are treated in some way (such as Hughes press, etc.) to liberate the toxin. Death seems to be due to chronic toxicity rather than acute toxicity. Attempts to affect the end point with antitoxin all failed perhaps because the antitoxin available was not sufficiently potent or perhaps because the toxin was already 'fixed' in some way by the brain and no longer susceptible to antitoxin.

Blyth (1955) and Andersen (1957) working with strains of B. pertussis of low mouse virulence found a sublethal infection in the brain similar to that which we found in the lung (Dolby et al. 1961). We did not find this sublethal type of infection in the brain with virulent strains (and possibly a fully susceptible strain of mice). In our experiments the smallest inoculum which lodged in the brain grew to a lethal level (Fig. 2). In experiments by the intracerebral route the mouse brain acts as a test tube of suitable medium until the point is reached at which the activities of the organism within the test tube become such that the test tube becomes leaky and any antibodies that happen to be outside can leak in. By the intracerebral route the challenge is so small that although at least $90 \%$ is lost at injection, 45,000 out of 50,000 , this was far too small a dose to act as an efficient vaccine.

A definition of a fully virulent strain could be, one which does not give rise to a sublethal infection; this definition stresses the ability of the parasite to lodge in the host rather than to grow in the host, since so long as infection is established in the brain the organism will always continue to multiply until the critical level of lethality is reached. 


\section{SUMMARY}

The growth of virulent strains of Bordetella pertussis in the brains of mice was studied by carrying out viable counts on mice killed at various times during the infection. The results suggested that this system conformed to the general model which postulates that the organisms causing death multiply in vivo at a rate which is constant for all doses and that death is certain to occur when the number of organisms reaches a certain constant figure.

Perhaps the most important factor in this route of infection is the lodgement of the parasite in the host, for if this is accomplished a single organism grows until the lethal level is reached. There is no sublethal infection.

In actively and passively protected mice, the growth of the organism is approximately the same as in unprotected controls for the first 4-5 days. At this time there is a striking change in protected animals and the viable count falls rapidly and progressively and the animals survive. At the same time the blood-brain barrier becomes permeable and circulating antibodies diffuse into the brain. In vitro, specific antisera plus complement are highly bactericidal.

One of the authors (J. M. D.) is a member of the External Staff, the Medical Research Council.

\section{REFERENCES}

Andersen, E. K. (1957). Demonstration of promunity in the early immunity of Pertussis vaccinated mice. Acta path. microbiol. scand. 40, 227.

Berenbaum, M. C., Ungar, J. \& Stevens, W. K. (1960). Intracranial infection of mice with Bordetella pertussis. J. gen. Microbiol. 22, 313.

BLyтн, W. A. (1955). The effects of immunity on the intracerebral infection of mice with Haemophilus pertussis. Thesis, Victoria University of Manchester.

Burnet, F. M. \& Timmins, C. (1937). Experimental infection with Haemophilus pertussis in the mouse by intranasal inoculation. Brit. J. exp. Path. 18, 83.

CaIRns, H. J. F. (1950). Intracerebral inoculation of mice. Fate of the inoculum. Nature, Lond., 166, 910.

DoLBY, J. M. (1958). The separation of the histamine-sensitizing factor from the protective antigens of Bordetella pertussis. Immunology, $1,144$.

Dolby, J. M. \& Standfast, A. F. B. (1958). A comparison of passive protection tests against intranasal and intracerebral challenges with Bordertella pertussis. Immunology, 1, 144.

Dolby, J. M., Thow, D. C. W. \& Standfast, A. F. B. (1961). The intranasal infection of mice with Bordetella pertussis. J. Hyg., Camb. 59, 191.

Holt, L. E., Spasojevic, V., Dolby, J. M. \& Standfast, A. F. B. (1961). Immunity in mice to intracerebral challenge using Bordetella pertussis. J. Hyg., Camb. (in the Press).

Hughes, D. E. (1951). A press for disrupting bacteria and other micro-organisms. Brit. J. exp. Path. 32, 97.

Kendrick, P. L., Eldering, G., Dixon, M. K. \& Misner, J. (1947). Mouse protection tests in the study of pertussis vaccine. Amer. J. publ. Hlth, 37, 803.

Mrtes, A. A. \& Misra, S. S. (1938). The estimation of the bactericidal power of the blood. J. Hyg., Camb. 38, 732.

Mrms, C. A. (1960). Intracerebral injections and the growth of viruses in the mouse brain. Brit. J. exp. Path. 41, 52.

Norton, J. F. \& Dingle, J. H. (1935). Virulence tests for typhoid bacilli and antibody relationships in antityphoid sera. Amer. J. publ. Hlth, 25, 609.

Pittman, M. (1956). Bacteriology-Pertussis and pertussis vaccine control. J. Wash. Acad. Sci. 46, 234.

StandFast, A. F. B. (1958). The comparison between field trials and mouse protection tests against intranasal and intracerebral challenges with Bordetella pertussis. Immunology, 1, 135.

U.S., N.I.H. (1948). Minimum Requirements. Pertussis Vaccine. National Institutes of Health, Bethesda, Md., U.S.A. 